\section{Morphological and Cytological Characterization of Five Porterweed (Stachytarpheta) Selections}

\section{Renjuan Qian}

Department of Environmental Horticulture, Gulf Coast Research and Education Center, University of Florida, Institute of Food and Agricultural Sciences (IFAS), Wimauma, FL 33598; and Zhejiang Institute of Subtropical Crops, 334 Xueshan Road, Wenzhou, Zhejiang 325005, China

\section{S. Brooks Parrish \\ Department of Environmental Horticulture, Gulf Coast Research and Education Center, University of Florida, IFAS, Wimauma, FL 33598}

Sandra B. Wilson

Department of Environmental Horticulture, University of Florida, IFAS, Gainesville, FL 32611

\section{Gary W. Knox}

Department of Environmental Horticulture, North Florida Research and Education Center, University of Florida, IFAS, Quincy, FL 32351

\section{Zhanao Deng}

Department of Environmental Horticulture, Gulf Coast Research and Education Center, University of Florida, IFAS, Wimauma, FL 33598

Additional index words. chromosome, DNA content, growth habit, ploidy, pollen, pollen stainability

\begin{abstract}
Porterweed (Stachytarpheta spp.), a member of the verbena family, is frequently used in pollinator gardens to attract butterflies. This study was conducted to assess the morphological features, pollen stainability and morphology, nuclear DNA content, and chromosome number of five porterweed selections. Coral porterweed ( $S$. mutabilis), 'Naples Lilac' porterweed $(S$. cayennensis $\times S$. mutabilis 'Violacea'), and nettleleaf porterweed $(S$. cayennensis) had the largest plant heights. Flower number was significantly higher in nettleleaf porterweed, jamaican porterweed (S. jamaicensis), and U*J3-2 porterweed (S. cayennensis $\times$ $S$.jamaicensis), with an average of 65-72 flowers per inflorescence. Internode length and flower width of jamaican porterweed had much lower values than the other selections. Coral porterweed recorded the lowest pollen stainability with only $10.6 \%$ stainability, but it had the largest relative pollen production. 'Naples Lilac' porterweed had the highest DNA content with an average of $3.79 \mathrm{pg} / 2 \mathrm{C}$, like jamaican porterweed with $3.73 \mathrm{pg} / 2 \mathrm{C}$. Ploidy levels varied between selections, and the basic chromosome number was $x=28$. Coral, jamaican, and 'Naples Lilac' porterweed had $2 n=6 x=168$ chromosomes, first reported in this genus. These results provide a guide and a new tool to distinguish native and non-native porterweed and may aid future breeding toward the production of noninvasive cultivars.
\end{abstract}

\footnotetext{
Received for publication 24 Nov. 2020. Accepted for publication 21 Dec. 2020

Published online 22 January 2021.

This project was funded in part by the U.S. Department of Agriculture, National Institute of Food and Agriculture (USDA/NIFA) Hatch projects (projects FLA-GCR-005065 and FLA-GCC-005507).

We gratefully acknowledge Boynton Botanicals (Boynton Beach, FL) for their original donation of some of the porterweed selections used in this study. We thank Joyce Jones, Gail Bowman, Zhe Cao, and Weining Wang for their assistance. We greatly appreciated that Drs. Kim Moore, Alfred Huo, and Kevin Begcy critically reviewed this manuscript before its submission and provided valuable comments. R.Q. is a visiting scholar at the University of Florida Z.D. is the corresponding author. E-mail: zdeng@ufl. edu.

This is an open access article distributed under the CC BY-NC-ND license (https://creativecommons. org/licenses/by-nc-nd/4.0/)
}

Porterweed (Stachytarpheta spp.) attracts numerous butterfly species and other pollinators and is often planted in pollinator gardens (Gilman, 2014). It is a low-maintenance plant with high drought tolerance and is commonly used in the southern United States in cold hardiness zones $9 \mathrm{~b}$ through 11 (Lamborn, 2017). Porterweed produces flowers from summer through fall before dying back during winter. The Stachytarpheta genus is vast, with 133 species identified in Australia (Munir, 1992) and 79 species classified in Brazil (Atkins, 2005). Seed is readily available to the public and can be found from many nurseries and online sellers. In the wild, seed is spread through the wind, vehicles, and machinery (The State of Queensland, 2016).
In Florida, the most sold porterweed species are jamaican porterweed (Stachytarpheta jamaicensis), nettleleaf porterweed (Stachytarpheta cayennensis), coral porterweed (Stachytarpheta mutabilis), purple porterweed (Stachytarpheta frantzii), and dwarf red porterweed (Stachytarpheta sanguinea) (http://plantANT.com). Jamaican porterweed is native to dunes, shell middens, pine rocklands, and disturbed sites of central and southern Florida (Wunderlin and Hansen, 2011); whereas nettleleaf porterweed was introduced to the United States from Central and South America and has escaped cultivation (USDA, NRCS, 2020). While it has not yet altered native plant communities in Florida, nettleleaf porterweed is listed as a Category II invasive plant by the Florida Exotic Plant Council (FLEPPC) due to its increased abundance or frequency (FLEPPC, 2019). The University of Florida Institute of Food and Agricultural Sciences's (UF/IFAS) status assessment of nonnative plants in Florida's natural areas is to "use with caution" (UF/ IFAS Assessment, 2020). Hybridization potential between the native and invasive congeners is of concern. For example, in Florida, the introduced lantana (Lantana camara) has hybridized with the native pineland lantana (Lantana depressa), contaminating the gene pool of the native species (Hammer, 2004; Sanders, 1987). Proper identification and distinction between native and invasive species are crucial components of reducing the spread of invasive ornamentals (Steppe et al., 2019). Although plant experts could observe some differences between jamaican and nettleleaf porterweed (Wunderlin and Hansen, 2011), these two species share a lot of similarities in plant morphology. These similarities make it difficult to identify them reliably before making decisions for invasive plant management, especially for those who are not familiar with porterweed plants.

In prior work, Wilson et al. (2009) evaluated seed production and viability of eight porterweed selections in Florida and found three of them to be highly female sterile. Female sterile porterweed included the following: 'Violacea' porterweed (Stachytarpheta mutabilis), 'Naples Lilac' porterweed (S. cayennensis $\times$ S. mutabilis 'Violacea'), and 'Mario Pollsa' porterweed (Stachytarpheta spp.). Through controlled crosses, the potential for nettleleaf porterweed to hybridize with jamaican porterweed was realized. However, there is a lack of information, such as ploidy level and pollen stainability on these porterweeds, which would be useful data in the breeding of noninvasive plants. Pollen staining has become a reliable method of determining pollen viability in hybridization studies (Czarnecki et al., 2014). Other porterweed studies have described pollen morphology and stainability for $S$. angustifolia, S. cayennensis, $S$. chamissonis, $S$. indica, and $S$. sericea (Adedeji, 2010; Atkins, 1991; Solanke et al., 2019). These studies revealed diverse morphologies and stainability of pollen grains

Chromosome number and ploidy level are important plant characteristics; the latter is an 
important factor in determining plant fertility and hybridization potential. It was previously reported that the porterweed genus has varying numbers of chromosomes, from $2 n=18$ to $2 n=160$, and varying levels of ploidy (Fedorov, 1974; Sanders, 2001). Flow cytometry has become a widely used tool to determine nuclear DNA content and ploidy level of plants due to high sample throughput (Doležel et al., 2007). Polyploids have been identified in porterweed using flow cytometry, but exact ploidy levels need to be determined or confirmed by chromosome counting (Wilson et al., 2009). To accurately interpret the ploidy level based on nuclear DNA content, somatic chromosomes must be determined to provide references for comparing nuclear DNA content (Doležel et al., 2007).

The purpose of this study was to characterize morphological and cytological features of five representative porterweed selections. The main objective was to count their chromosomes in root tip cells, determine nuclear DNA contents by flow cytometrical analysis of leaf tissues, and understand the relationship between ploidy level and nuclear DNA content in porterweed. A secondary objective was to assess pollen morphology and stainability among these porterweed selections. This information, along with complete leaf and flower morphological profiling, will improve identification, promote the use of native porterweed, and control the further spread of invasive porterweed.

\section{Materials and Methods}

Plant materials. Five porterweed selections were evaluated in this study. Coral, jamaican, 'Naples Lilac', and nettleleaf porterweed plants were obtained from a previous study conducted by Wilson et al. (2009). $\mathrm{U}^{*} \mathrm{~J} 3-2$ resulted from controlled crossing of $S$. cayennensis and $S$. jamaicensis in a greenhouse located at the UF/IFAS Gulf Coast Research and Education Center (Wimauma, FL). Vegetatively propagated porterweed plants were grown in 3.8-L plastic containers filled with Fafard 2P mix (Florida Potting Soil, Orlando, FL). Container-grown plants were hand-watered daily and fertilized with a controlled-release fertilizer (Osmocote; $15 \mathrm{~N}-3.9 \mathrm{P}-10 \mathrm{~K}, 5$ to 6 months release at $21{ }^{\circ} \mathrm{C}$; The Scotts Company, Marysville, $\mathrm{OH})$ at $6.51 \mathrm{~kg} \cdot \mathrm{m}^{-3}$. Plants were grown between July and Nov. 2014 under natural light in a temperature-controlled greenhouse with a temperature of $29.4{ }^{\circ} \mathrm{C}$ during the day and $21.1^{\circ} \mathrm{C}$ at night.

Morphological characterization. Mature flowering plants $(\approx 100 \mathrm{~d}$ after cuttings were made) were used to collect plant morphological data. Growth habit was identified as upright, semiupright, or prostrate. Plant height, plant width for two perpendicular axes, and inflorescence length were recorded using a standard wooden meter stick. Leaf length, leaf width, and internode length were measured using a stainless-steel ruler. Internode diameter and flower width were determined using an electronic digital caliper
(Fowler \& NSK Max-Cal, Japan). Five replicates (five individual plants) were accessed for each porterweed selection.

Determining nuclear DNA content. An Accuri C6 flow cytometer (BD Biosciences, San Jose, CA) at the UF's Interdisciplinary Center for Biotechnology Research (ICBR, Gainesville, FL) was used to determine nuclear DNA content. The flow cytometry protocol recommended by Doležel et al. (2007) was followed using rye [Secale cereal 'Daňkovské' (16.19 pg/2C)] as the internal standard. One $\mathrm{mL}$ of the LBO1 lysis buffer (Doležel et al., 2007) was added to a petri dish, and $\approx 30 \mathrm{mg}$ of tender leaf tissue of porterweed and rye were chopped together using a razor blade to release nuclei. The nuclei preparation was filtered through a nylon mesh $(50 \mu \mathrm{m})$ into a loading tube, and then $50 \mu \mathrm{L}$ of the DNA fluorochrome propidium iodide (Sigma-Aldrich; $1 \mathrm{mg} \cdot \mathrm{mL}^{-1}$ ) and RNase (Sigma-Aldrich; $1 \mathrm{mg} \cdot \mathrm{mL}^{-1}$ ) were added. The nuclei-containing solution was fed into the flow cytometer. Three flow cytometrical analyses were run for each porterweed selection, and a minimum of 3000 nuclei were counted per run. Nuclear DNA content (pg/2C) was calculated according to Doležel et al. (2007): sample DNA content $=$ nuclear DNA content of internal standard ('Daňkovské' rye) $\times$ (mean fluorescence value of sample $\div$ mean fluorescence value of internal standard).

Squashing and counting chromosomes. The cell wall degradation hypotonic method of Chen et al. (1982) was used. Before 10:00 $\mathrm{AM}$, vigorously growing root tips $(1 \mathrm{~cm})$ were excised from porterweed plants and treated in $0.002 \mathrm{M} 8$-hydroxyquinoline for $4 \mathrm{~h}$ in the dark. Root tips were fixed in a fixative solution ( 3 methanol: 1 acetic acid, v/v) for at least $2 \mathrm{~h}$. The fixed roots were rinsed three times in deionized water before a much smaller section of the root tips $(\approx 1 \mathrm{~mm})$ was excised and macerated in an enzyme solution containing $2.5 \%$ cellulase and $2.5 \%$ pectinase for $3 \mathrm{~h} 15 \mathrm{~min}$ inside an incubator at $27^{\circ} \mathrm{C}$. After incubation, macerated root tips were washed in deionized water for $10 \mathrm{~min}$ and then fixed in a fixative solution (3 methanol: 1 acetic acid, v/v) for $0.5 \mathrm{~h}$. Root tips were squashed in a drop of the fixative solution on a pre-chilled microscopic glass slide. The prepared slide was heated over an alcohol burner for a few seconds and stained with a $2.5 \%$ Giemsa solution for $10 \mathrm{~min}$. Stained glass slides were rinsed in distilled water, air-dried, and then observed under a BX41 microscope with an Olympus Q-color 5 camera (Olympus America Inc., Melville, NY). Darkly stained and well-spread chromosomes were photographed at $\times 1000 \mathrm{mag}$ nification.

Examining and staining pollen grains. Flowers were collected just before opening and dissected to reveal anther sacs. Predehiscent anthers were removed and immersed in $100 \mu \mathrm{L}$ of cotton blue stain in microcentrifuge tubes. Tubes were placed in a $65{ }^{\circ} \mathrm{C}$ water bath where anthers were stained overnight. Stained anthers were rinsed three times in water, squashed in 50 $\mu 1$ of $80 \%$ glycerol on a microscopic glass slide, and then covered with a glass coverslip. A BX41 microscope with an Olympus Qcolor 5 camera (Olympus America Inc.) was used to observe pollen grains at $\times 40$ and $\times 100$ magnification. Images of pollen grains were taken and analyzed to calculate pollen stainability. Pollen grains stained dark blue were considered stainable. Measurements of pollen grains were taken using ImageJ $1.52 \mathrm{~s}$ (U.S. National Institutes of Health, Bethesda, $\mathrm{MD})$. At least 12 anthers from three inflorescences were analyzed for each porterweed selection. Two slides were prepared for each selection, and three fields of view were selected at random and photographed. Each pollen grain was counted and used to calculate relative pollen stainability. Pollen grain density was compared with other selections for relative production.

Statistical analysis. Analysis of variance was performed in JMP Pro 15.0.0 (SAS Institute, Cary, NC) to determine if there were significant differences among porterweed selections in plant height and width, leaf length and width, inflorescence number, flower number, flower width, and pollen stainability. When differences were significant at $P \leq 0.05$, mean separation analysis was performed in JMP Pro 15.0.0 using the Tukey-Kramer honestly significant difference procedure at $P \leq 0.05$. Linear regression was performed using JMP Pro 15.0.0 to determine if a correlation existed between two traits. The Pearson correlation test was used to calculate the correlation coefficient.

\section{Results and Discussion}

Morphological characterization. Remarkable variability was observed among the morphological features of the five porterweed selections. Porterweed growth habits were categorized as upright, semiupright, and prostrate, with two selections each falling into upright and prostrate, and nettleleaf identified as semiupright (Table 1, Fig. 1). Coral and 'Naples Lilac' plants were upright with shoots extending upwards. Coral porterweed showed little branching with pink-tocoral flowers, while 'Naples Lilac' had a fuller appearance with purple flowers (Fig. 2A). Nettleleaf porterweed exhibited a semiupright growth habit with darker-purple flowers. Plants of this selection grew partially to the side of the pot, extending away from the base and partially extending upward. $\mathrm{U}^{*} \mathrm{~J} 3-2$ and jamaican porterweed were both prostrate with low, spreading growth. Both selections had high branching, but jamaican porterweed filled the area surrounding all sides of the pot instead of just one side. U*J3-2 displayed purple flowers and jamaican porterweed had light purple. Leaf morphology was identified as ovate for all selections (Fig. 2B). Classification of these growth habits and flower colors alone provides substantial clues to identifying these porterweed selections. For example, distinguishing invasive nettleleaf from the native 
Table 1. Plant, leaf, and flower morphological data of five porterweed selections. Data were collected on five plants of each selection grown at the University of Florida's Gulf Coast Research and Education Center.

\begin{tabular}{|c|c|c|c|c|c|c|c|c|c|c|c|}
\hline & Taxa & $\begin{array}{c}\text { Growth } \\
\text { habit }\end{array}$ & Plant $h t^{z}$ & $\begin{array}{l}\text { Plant } \\
\text { width }\end{array}$ & $\begin{array}{l}\text { Leaf } \\
\text { length }\end{array}$ & $\begin{array}{l}\text { Leaf } \\
\text { width }\end{array}$ & $\begin{array}{c}\text { Internode } \\
\text { length }\end{array}$ & $\begin{array}{l}\text { Internode } \\
\text { diam }\end{array}$ & $\begin{array}{l}\text { Inflorescence } \\
\text { length }\end{array}$ & $\begin{array}{l}\text { Flower } \\
\text { number }\end{array}$ & $\begin{array}{l}\text { Flower } \\
\text { width }\end{array}$ \\
\hline $\begin{array}{l}\text { Naples } \\
\text { Lilac }\end{array}$ & $\begin{array}{l}\text { (S. cayennensis } \times \\
\quad \text { S. mutabilis } \\
\text { 'Violacea') }\end{array}$ & Upright & $59.8 \mathrm{a}$ & $63.9 \mathrm{~b}$ & $15.6 \mathrm{~b}$ & $7.2 \mathrm{~b}$ & $9.8 \mathrm{ab}$ & $13.1 \mathrm{a}$ & $66.1 \mathrm{a}$ & $30.2 \mathrm{~b}$ & $1.5 \mathrm{~b}$ \\
\hline Nettleleaf & (S. cayennensis) & Semi-upright & $46.0 \mathrm{~b}$ & $62.3 \mathrm{~b}$ & $13.7 \mathrm{~b}$ & $6.2 \mathrm{bc}$ & $10.1 \mathrm{a}$ & $12.4 \mathrm{a}$ & $45.4 \mathrm{~b}$ & $71.6 \mathrm{a}$ & $1.3 \mathrm{c}$ \\
\hline U*J3-2 & $\begin{array}{r}\text { (S. cayennensis } \times \\
\quad \text { S. jamaicensis) }\end{array}$ & Prostrate & $36.1 \mathrm{~b}$ & $80.0 \mathrm{a}$ & $14.7 \mathrm{~b}$ & $6.4 \mathrm{~b}$ & $11.8 \mathrm{a}$ & $12.3 \mathrm{a}$ & $68.8 \mathrm{a}$ & $65.8 \mathrm{a}$ & $1.3 \mathrm{c}$ \\
\hline
\end{tabular}

${ }^{\mathrm{z}}$ Means followed by a common letter within each column are not significantly different by Tukey's honestly significant difference test at the $5 \%$ level of significance.
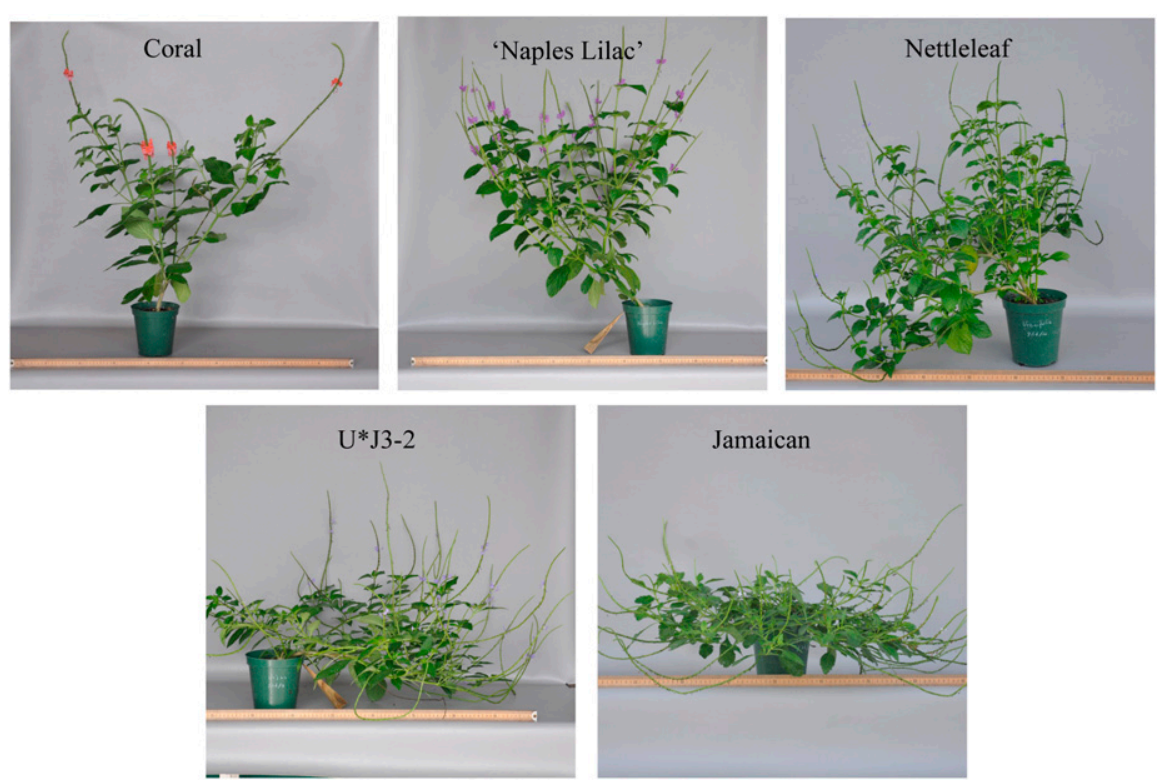

Fig. 1. Images of each porterweed selection at the time of data collection. Plants were propagated at the same time and grown under the same conditions.

jamaican porterweed can be determined by assessing the direction of growth and the intensity of purple colors in the flowers.

The range of flower number per inflorescence varied greatly, with a maximum of 80 flowers in nettleleaf porterweed and a minimum of 8 flowers per inflorescence in coral porterweed. Flower number was fewer in coral porterweed, with an average of only 11.2 flowers. Plant height was another morphological feature that largely differed between selections, ranging from $60.1 \mathrm{~cm}$ in coral porterweed to $18.1 \mathrm{~cm}$ in jamaican porterweed. Coral porterweed had larger leaves than the other selections, with an average length of $23.1 \mathrm{~cm}$ and a width of $10.3 \mathrm{~cm}$ (Table 1). U*J3-2, a line resulting from an interspecific cross between nettleleaf and jamaican porterweed, showed a significantly higher plant width of $80 \mathrm{~cm}$, compared with both parents and all other selections in the study.

Recording few numbers of flowers per inflorescence, coral porterweed had the highest average flower width of $1.7 \mathrm{~cm}$. 'Naples Lilac' had a high plant height of $59.8 \mathrm{~cm}$ and the highest average internode diameter of $13.1 \mathrm{~mm}$. Nettleleaf porterweed had a rela- tively small inflorescence length of only $45.40 \mathrm{~cm}$ (Fig. 2C). Inflorescence length was the highest in $\mathrm{U}^{*} \mathrm{~J} 3-2$, extending 68.8 $\mathrm{cm}$. Jamaican porterweed was the shortest plant in the study, only reaching $18.1 \mathrm{~cm}$ in height. It had the smallest leaf width of 5.0 $\mathrm{cm}$ and a small flower width of only $1 \mathrm{~cm}$. It is of interest to note that $\mathrm{U}^{*} \mathrm{~J} 3-2$ was similar in plant height, internode length, internode diameter, and flower width to its female parent (nettleleaf porterweed), but it was similar in leaf length, leaf width, and flower number to both of its parents. The hybrid's plant width was significantly wider than both parents. Similar segregation of traits was observed in the hybridization of $S$. angustifolia $\times S$. cayennensis produced by Solanke et al. (2019).

These results were consistent with prior findings (Wilson et al., 2009) where flower quality was assessed monthly for 7 months and rated $1-5$ based on the number of spikes and number of open flowers. Coral porterweed had fewer flower spikes and lower flower-quality ratings than other selections, while nettleleaf porterweed had the most flower spikes resulting in overall higher flower ratings. While flower quantity can be important for both aesthetic appeal and attraction of pollinators, a negative consequence in the case of an escaped non-native ornamental is seed production and subsequent seedling establishment. In the prior study, it was estimated that an average coral porterweed plant has the potential to produce only 70 seedlings per growing season, whereas nettleleaf porterweed has the potential to produce 26,600 seedlings.

Identifying porterweed by flower color alone can be difficult without thorough experience working with the genus. The morphological traits identified in this study such as leaf size and growth habit may enable us to identify porterweed in ecosystems with greater accuracy. Also, the growth habit and inflorescence length of the invasive nettleleaf porterweed are important features that can aid in identifying and removing this species in the United States.

Nuclear DNA content. Standard deviation values for the mean nuclear DNA content of five porterweed selections were $\leq 0.09 \mathrm{pg}$, suggesting that this method is robust (Table 2). Nuclear DNA content for the selections ranged from $2.81 \mathrm{pg} / 2 \mathrm{C}$ in nettleleaf porterweed to $3.79 \mathrm{pg} / 2 \mathrm{C}$ in 'Naples Lilac'. This is of interest, because 'Naples Lilac' is reported to be a cross between the invasive nettleleaf porterweed and the noninvasive 'Violacea' porterweed (S. mutabilis) (Kastenholz, personal communication). Coral and jamaican porterweed had similar DNA contents of $3.66 \mathrm{pg} / 2 \mathrm{C}$ and $3.73 \mathrm{pg} / 2 \mathrm{C}$. The nuclear DNA content of $\mathrm{U}^{*} \mathrm{~J} 3-2$ was 3.28 $\mathrm{pg} / 2 \mathrm{C}$, close to the average of the nuclear DNA content of jamaican and nettleleaf porterweed. Nuclear DNA content data for the genus Stachytarpheta are not available in the plant DNA C-value database (Pellicer and Leitch, 2019). Our data will help fill this gap in the widely used database.

Chromosome counts. A total of 182 wellspread metaphases were observed, photographed, and counted to determine the somatic chromosome number for all five selections (Fig. 3). At least 31 metaphases were observed for each selection, which revealed three chromosome numbers $(2 n=$ $4 x=112,2 n=5 x=140$, and $2 n=6 x=168)$ (Table 2). Coral, jamaican, and 'Naples Lilac' porterweed recorded a large somatic chromosome number of 168 . U*J3-2 porterweed had 140 chromosomes, and nettleleaf 

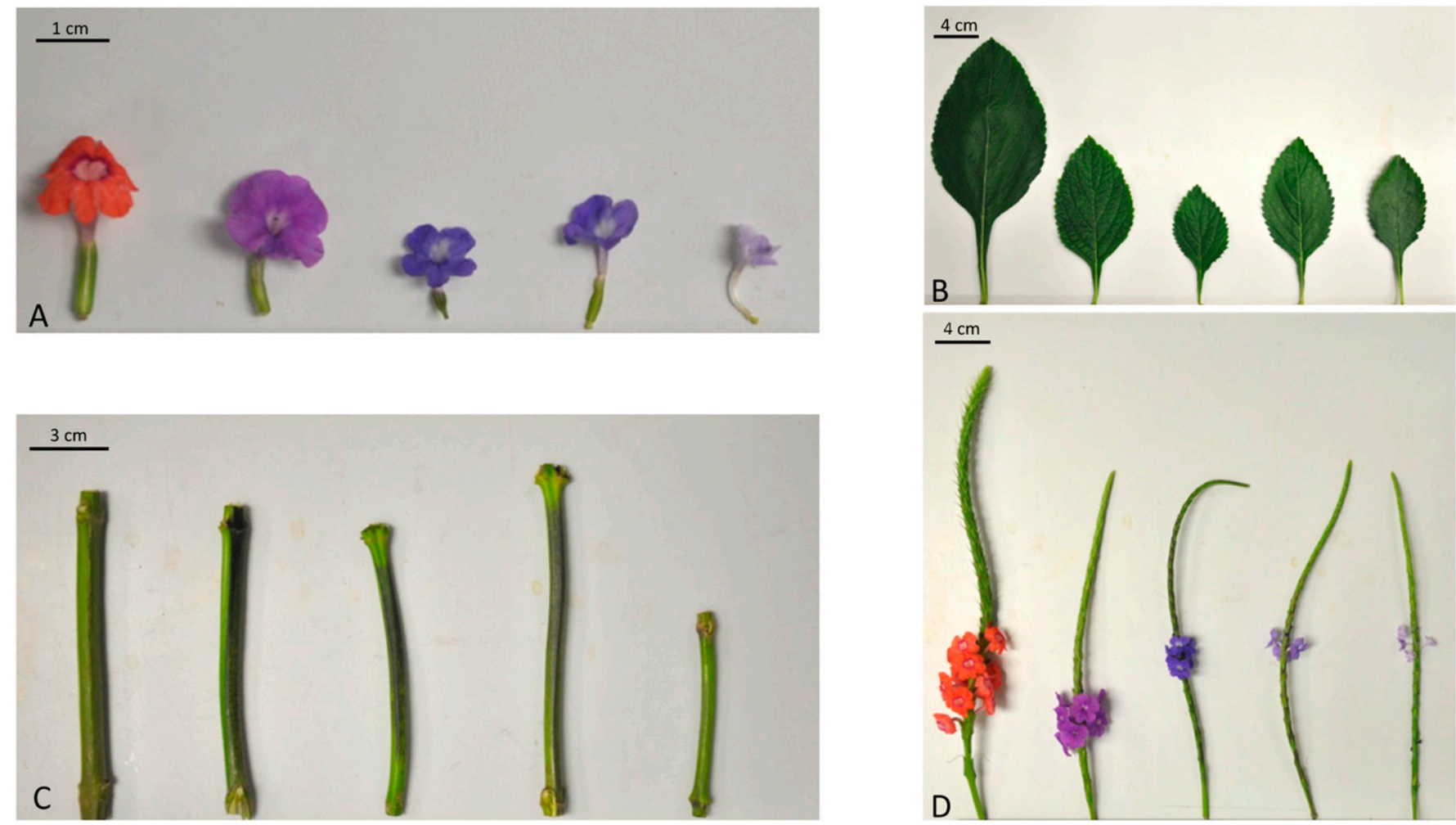

Fig. 2. Morphology of porterweed open flowers (A), leaves (B), internodes (C), and inflorescences (D). Left to right: Coral porterweed, 'Naples Lilac' porterweed, nettleleaf porterweed, $\mathrm{U}^{*} \mathrm{~J} 3-2$ porterweed, and jamaican porterweed.

Table 2. Nuclear DNA content and chromosome number of five porterweed selections. Three flow cytometrical analyses were run for each porterweed selection.

\begin{tabular}{lccccc}
\hline Taxa & $\begin{array}{c}\text { Nuclear DNA } \\
\text { content } \pm \text { SD }(\mathrm{pg} / 2 \mathrm{C})\end{array}$ & $\begin{array}{c}\text { Metaphases } \\
\text { observed (no.) }\end{array}$ & $\begin{array}{c}\text { Chromosome } \\
\text { number }\end{array}$ & $\begin{array}{c}\text { Base chromosome } \\
\text { number }\end{array}$ & $\begin{array}{c}\text { Ploidy } \\
\text { level }\end{array}$ \\
\hline Coral & $3.66 \pm 0.05$ & 38 & 168 & 28 & $6 x$ \\
Naples Lilac & $3.79 \pm 0.04$ & 41 & 168 & 28 & $6 x$ \\
Nettleleaf & $2.81 \pm 0.03$ & 36 & 112 & 28 & $4 x$ \\
U*J3-2 & $3.28 \pm 0.05$ & 36 & 140 & 28 & $5 x$ \\
Jamaican & $3.73 \pm 0.09$ & 31 & 168 & 28 & $6 x$ \\
\hline
\end{tabular}

porterweed had 112 somatic chromosomes. All selections have the same basic chromosome number $(x=28)$.

Literature indicated $2 n=18,48,56$, $\approx 120$, and 160 chromosomes in Stachytarpheta (Sanders, 2001). These chromosome numbers were based mostly on observations in S. cayennensis (Sanders, 2001), and there has been a lack of information on the chromosome numbers for many other Stachytarpheta species (Rice et al., 2015; Sanders, 2001). Our chromosome counting data represent the first for $S$. jamaicensis and $S$. mutabilis and the largest chromosome numbers in the genus. This is also the first report of a chromosome number for a hybrid between nettleleaf and jamaican porterweed, which was identified as a pentaploid.

There was a linear positive relationship $\left(R^{2}=0.9831, P<0.001\right)$ between chromosome number and DNA content in these selections. This positive relationship may allow inferences of ploidy level to be made based on nuclear DNA content in these species.

Effects of polyploids on plant, stem, leaf, and flower morphology have been docu- mented in many plants. The existence of three ploidy levels among these selections prompted us to perform regression analysis to find out if there were any relationships between ploidy level and morphological parameters [including plant height and width, leaf length and width, internode length and diameter, flower number (per inflorescence) and width, and length of inflorescences]. A strong linear relationship was observed between ploidy level and length of inflorescences $\left(R^{2}=0.7970, P<\right.$ $0.0001)$, and plant width $\left(R^{2}=0.7092, P<\right.$ 0.001 ) (Table 3 ). A similar relationship was also observed between ploidy level and flower number $\left(R^{2}=0.4477, P<0.0015\right)$ and internode length $\left(R^{2}=0.3175, P<\right.$ $0.0150)$. Such a relationship was not detected with plant height, leaf length and width, internode diameter, or flower width. It should be pointed out that because of the limited number of selections available for this study, these linear relationships should be considered preliminary. Many more selections of different ploidy levels should be assessed to gain a better understanding of

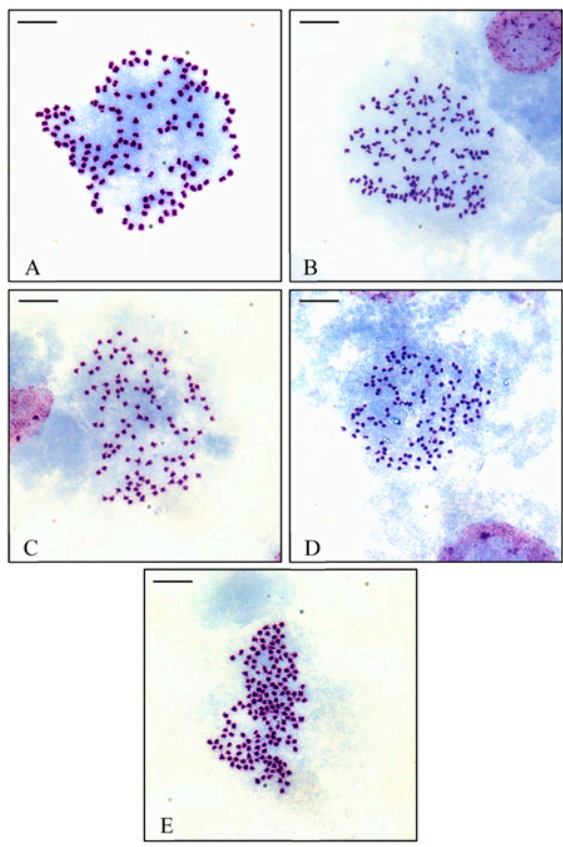

Fig. 3. Micrographs $(\times 1000)$ of somatic chromosomes observed in root tip cells stained in Giemsa. (A) Coral porterweed $(2 n=168)$. (B) 'Naples Lilac' porterweed $(2 n=168)$. (C) Nettleleaf porterweed $(2 n=112)$. (D) U*J3-2 porterweed $(2 n=140)$. (E) Jamaican porterweed $(2 n=168)$. Scale bar $=10 \mu \mathrm{m}$.

the effects of polyploidy on porterweed morphology.

The identification of polyploids is necessary for breeders to use ploidy manipulation 
Table 3. Summary results from regression analysis to detect potential relationship between ploidy level and porterweed plant, leaf, stem, flower, and inflorescence morphological parameters.

\begin{tabular}{|c|c|c|c|c|c|c|c|c|c|}
\hline & \multicolumn{2}{|c|}{ Plant } & \multicolumn{2}{|c|}{$\begin{array}{c}\text { Leaves } \\
\end{array}$} & \multicolumn{2}{|c|}{ Internodes } & \multicolumn{2}{|c|}{ Flowers } & \multirow[b]{2}{*}{ Inflorescence length } \\
\hline & $\mathrm{Ht}$ & Width & Length & Width & Length & Diam & Number & Width & \\
\hline$\overline{R^{2}}$ & 0.0554 & 0.7092 & 0.1389 & 0.0968 & 0.3175 & 0.0987 & 0.4477 & 0.0390 & 0.7970 \\
\hline$P$ & 0.5345 & $<0.0001$ & 0.1931 & 0.3265 & 0.0150 & 0.3190 & 0.0015 & 0.6454 & $<0.0001$ \\
\hline
\end{tabular}

Table 4. Relative quantity, shape, size, and stainability of pollen grains of five porterweed selections. At least twelve anthers from three inflorescences per selection were used for analysis.

\begin{tabular}{lclcc}
\hline Taxa & $\begin{array}{c}\text { Relative pollen } \\
\text { production }\end{array}$ & \multicolumn{1}{c}{ Shape } & $\begin{array}{c}\text { Pollen length Pollen } \\
\pm \mathrm{SD}(\mu \mathrm{m})^{\mathrm{z}}\end{array}$ & $\begin{array}{c}\text { stainability Pollen } \\
\pm \mathrm{SD}(\%)^{\mathrm{z}}\end{array}$ \\
\hline $\begin{array}{l}\text { Coral } \\
\text { Naples Lilac }\end{array}$ & ++++ & Triangular & $252.1 \pm 9.8 \mathrm{a}$ & $10.6 \pm 3.6$ \\
Nettleleaf & + & $\begin{array}{l}\text { Round } \\
\text { Triangular }\end{array}$ & $143.6 \pm 9.5 \mathrm{c}$ & - \\
$\mathrm{U}^{*} \mathrm{~J} 3-2$ & + & $\begin{array}{l}\text { Variable (round } \\
\text { irregular) }\end{array}$ & $134.3 \pm 9.2 \mathrm{~b}$ & $44.0 \pm 8.1$ \\
Jamaican & + & $\begin{array}{c}130.5 \mathrm{c} \\
\text { Triangular }\end{array}$ & $180.3 \pm 3.2 \mathrm{~b}$ & - \\
\hline
\end{tabular}

${ }^{\mathrm{z}}$ Means followed by a common letter within column are not significantly different by Tukey's honestly significant difference test at the $5 \%$ level of significance. "- " indicates further studies needed.

in generating noninvasive sterile cultivars. Sterile cultivars of Lantana camara have successfully been developed by the crossing of tetraploids and diploids (Czarnecki et al., 2014; Deng et al., 2017, 2020). U*J3-2 was identified as a pentaploid in this study and will need further research to assess its degree of male and female sterility or infertility. Wilson et al. (2009) identified 'J.P.'s Pink' (S. speciosa) and 'Red Compact' (S. speciosa) porterweed as diploid species, making them potential candidates for crosses with nowidentified tetraploid nettleleaf porterweed. Furthermore, confirming polyploids through chromosome staining has laid the groundwork for determining the ploidy of other porterweed species with flow cytometry.

Quantity, morphology, and stainability of pollen grains. Pollen production varied between selections, with coral porterweed having the largest relative pollen production (Table 4). Pollen staining was reported only for coral, jamaican, and nettleleaf porterweed. Reliable staining results were not available for 'Naples Lilac' and U*J3-2, two interspecific hybrids. Future research is needed using different staining procedures or pollen germination to determine their pollen stainability or viability.

Coral, jamaican, and nettleleaf porterweed had triangular pollen grains, as opposed to 'Naples Lilac', which had round pollen grains; and $\mathrm{U}^{*} \mathrm{~J} 3-2$ had variably shaped pollen grains (Fig. 4). Variability was observed in the size of pollen grains among these selections. Coral porterweed had the largest pollen grains, with an average length of $252 \mu \mathrm{m}$. Jamaican and nettleleaf porterweed had much smaller pollen, measuring $180.3 \mu \mathrm{m}$ and $174.3 \mu \mathrm{m}$, respectively. 'Naples Lilac' and $\mathrm{U} * \mathrm{~J} 3-2$ had diameters of $130.5-143.6 \mu \mathrm{m}$. Average pollen diameter for nettleleaf porterweed was reported as $116.5 \mu \mathrm{m}$ by Adedeji (2010), differing from this study by $57.8 \mu \mathrm{m}$. However, the previous study observed high variability in pollen grain size and observed several different pollen shapes, perhaps accounting for the difference in diameter. No linear relationship was detected between ploidy level and pollen grain size in these porterweed selections when the pentaploid U*J3-2 was included or excluded (data not shown).

Coral porterweed recorded the lowest pollen stainability, with only $10.6 \%$ stainability. Nettleleaf and jamaican porterweed had $44.0 \%$ or $51.4 \%$ pollen stainability, and they also had the highest fruit set and seed viability in the previous study (2009). High male and female fertility have contributed to the presence of these two selections in the southern ecosystems. Solanke et al. (2019) reported pollen stainability for nettleleaf porterweed at $87.8 \%$, nearly double that observed in the present study. This difference could be due to the duration of cotton blue staining, where the former study allowed pollen to stain for $48 \mathrm{~h}$. Pollen stainability results for 'Naples Lilac' and $\mathrm{U}^{*} \mathrm{~J} 3-2$ were not presented in this study due to issues with staining of the pollen grains of these two selections.

Pollen staining results indicate that coral porterweed is the only selection analyzed with potential male sterility. This finding, along with lower female fertility identified in the previous study, makes coral porterweed a possible infertile alternative for landscapes. More research is needed to understand why coral porterweed was not like the other two hexaploids (jamaican and 'Naples Lilac') but showed a much lower pollen stainability.

In summary, species evaluated within the porterweed complex differed widely in their leaf and floral morphology, chromosome number, and pollen stainability. This is a first report confirming ploidy level variation among these selections. Our study showed that the Florida native (jamaican porterweed), the introduced species (nettleleaf porterweed), and their progeny (U*J3-2) are distinctly different in nuclear DNA content and chromosome number. These differences should provide a reliable tool to differentiate the native from the introduced porterweed in cases where morphological identification becomes difficult. This information may not

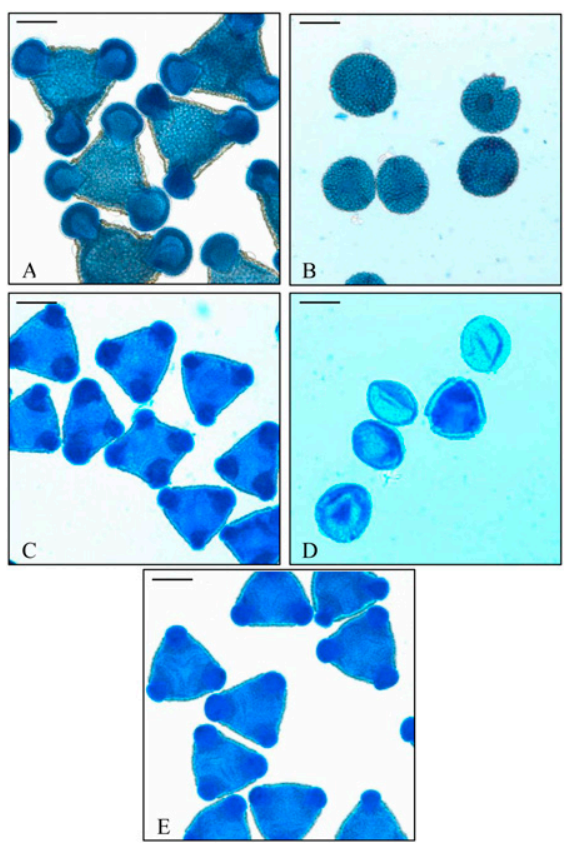

Fig. 4. Micrographs $(\times 100)$ of pollen grains stained in cotton blue for $5 \mathrm{~h}$. (A) Coral porterweed. (B) 'Naples Lilac' porterweed. (C) Nettleleaf porterweed. (D) U*J3-2 porterweed. (E) Jamaican porterweed. Scale bar $=100 \mu \mathrm{m}$.

only be useful in future breeding programs, but also may be a consideration for selecting noninvasive traits. Of the porterweed selections examined, coral porterweed stands out as having low pollen stainability and low female fertility that were reduced by $76 \%$ and $83 \%$, respectively, compared with the invasive nettleleaf porterweed. Comprehensive morphological comparisons among porterweed selections presented herein will greatly aid in their proper identification and sustainable use in Florida.

\section{Literature Cited}

Adedeji, O. 2010. Palynology of the genus Stachytarpheta Vahl. (Verbenacae). Not. Sci. Biol. 2:27-33, doi: $10.15835 / \mathrm{nsb} 244816$

Atkins, S. 1991. Stachytarpheta sericea Atkins (Verbenaceae) and its hybrid with S. chamissonis Walp. Kew Bull. 46:281-289, doi: $10.2307 / 4110597$

Atkins, S. 2005. The genus Stachytarpheta (Verbenaceae) in Brazil. Kew Bul. 60:161-272. $<$ https://www.jstor.org/stable/4110935>.

Czarnecki, D.M., A.J. Hershberger, C.D. Robacker, D.G. Clark, and Z. Deng. 2014. Ploidy levels and pollen stainability of Lantana camara cultivars and breeding lines. HortScience 49:1271-1276, doi: 10.21273/HORTSCI.49.10.1271.

Chen, R.Y., W.Q. Song, and X.L. Li. 1982. Wall degradation hypotonic method of preparing 
chromosome samples in plant and its significance in the cytogenetics. Acta Genet. Sin. 9:151-159.

Deng, Z., S.B. Wilson, X. Ying, and D.M. Czarnecki. 2017. Infertile Lantana camara cultivars UF-1011-2 and UF-1013A-2A. HortScience 52:652-657, doi: 10.21273/hortsci11840-17.

Deng, Z., S.B. Wilson, X. Ying, C. Chen, R Rreyre, V. Zayas, and D.M. Czarnecki. 2020. 'UF-1013-1': An infertile cultivar of Lantana camara. HortScience 55(6):953-958, doi: 10.21273/HORTSCI14911-20.

Doležel, J., J. Greilhuber, and J. Suda. 2007. Estimation of nuclear DNA content in plants using flow cytometry. Nat. Protoc. 2:22332244, doi: 10.1038/nprot.2007.310.

Fedorov, A. 1974. Chromsome numbers of flowering plants. Otto Koeltz, Koenigstein.

Florida Exotic Pest Plant Council (FLEPPC). 2019. Florida exotic pest plant council's 2019 list of invasive plant species. 25 Mar. 2020. <https:// www.fleppc.org $>$.

Gilman, E.F. 2014. Stachytarpheta jamaicensis blue porterweed. University of Florida Institute of Food and Agricultural Sciences (IFAS) Fact Sheet, FPS-559. 25 Mar. 2020. <http://edis.ifas. ufl.edu/FP559>.

Hammer, R.L. 2004. The lantana mess: A critical look at the genus in Florida. The Palmetto 23:21-24. <https://www.fnps.org/assets/pdf/ palmetto/v23n1lantanacorrection.pdf $>$.
Lamborn, A.R. 2017. Porterweed Stachytarpheta spp. University of Florida Institute of Food and Agricultural Sciences (IFAS) Extension Baker County. 25 Mar. 2020. <https://sfyl.ifas.ufl.edu/ media/sfylifasufledu/baker/docs/pdf/horticulture/ demonstration-gardens/Porterweed.pdf $>$.

Munir, A.A. 1992. A taxonomic revision of the genus Stachytarpheta Vahl (Verbenaceae) in Australia. J. Adel. Bot. Gard. 14:133-168. $<$ https://www.jstor.org/stable/23874423>.

Pellicer, J. and I.J. Leitch. 2019. The plant DNA Cvalue database (release 7.1): An updated online repository of plant genome size data for comparative studies. New Phytol. 226:301-305, doi: 10.1111/nph.16261.

Rice, A., L. Glick, S. Abadi, M. Einhorn, N.M. Kopelman, A. Salman-Minkov, J. Maywel, O. Chay, and I. Mayrose. 2015. The chromosome counts database (CCDB) - A community resource of plant chromosome numbers. New Phytol. 206(1):19-26, doi: 10.1111/nph.13191.

Sanders, R.W. 1987. Identify of Lantana depressa and L. ovatifolia (Verbenaceae) of Florida and the Bahamas. Syst. Bot. 12(1):44-60, doi: $10.2307 / 2419214$.

Sanders, R.W. 2001. The genera of Verbenaceae in the southeastern United States. Harv. Pap. Bot. 5:303-358. <https://www.jstor.org/stable/ 41761611>.

Solanke, D.S., M. Oziegbe, and S.O. Azeez. 2019. Interspecific hybridization studies of three Sta- chytarpheta species from Nigeria. Jordan J. Biol. Sci. 12:435-440.

Steppe, C., S.B. Wilson, Z. Deng, K. Druffel, and G.W Knox. 2019. Morphological and cytological comparison of eight varieties of trailing lantana (Lantana montevidensis) grown in Florida. HortScience 54:2134-2138, doi: 10.21273/hortsci14443-19.

The State of Queensland, Department of Agriculture and Fisheries. 2016. Weeds of Australiabiosecurity Queensland edition fact sheetStachytarpheta cayennensis. 25 Mar. 2020. $<$ https://keyserver.lucidcentral.org/weeds/data/ media/Html/stachytarpheta_cayennensis.pdf $>$.

University of Florida, Institute of Food and Agricultural Sciences (UF/IFAS). 2020. Assessment of non-native plants in Florida's natural areas. Stachytarpheta cayennensis. 10 Apr. 2020. $<$ https://assessment.ifas.ufl.edu/assessments/ stachytarpheta-cayennensis/>.

USDA, NRCS. 2020. The PLANTS Database. National Plant Data Team, Greensboro, NC. 25 Mar. 2020. <https://plants.usda.gov/core/ profile? symbol=STUR $>$.

Wilson, S.D., G.W. Knox, K.L. Muller, R. Freyre, and Z. Deng. 2009. Seed production and viability of eight porterweed selections grown in northern and southern Florida. HortScience 44:18421849, doi: 10.21273/hortsci.44.7.1842.

Wunderlin, R.P. and B.F. Hansen. 2011. Guide to the vascular plants of Florida. 3rd ed. University Press of Florida, Gainesville. 